\title{
Continent elevation, mountains, and erosion: Freeboard implications
}

\author{
J. A. Whitehead ${ }^{1}$ and Peter D. Clift $^{2}$ \\ Received 28 October 2008; revised 16 February 2009; accepted 25 February 2009; published 21 May 2009.
}

[1] To the simplest approximation, Earth's continental crust is a floating aggregate on the planet's surface that is first attracted to subduction zones and, upon arrival, thickened by mountain building (then producing some extension). Thickened regions are thinned again by erosion. A comparison between $65 \mathrm{Ma}$ and the present shows that the modern state is significantly more mountainous. An estimated average continental elevation increase relative to average ocean floor depth of about $54 \mathrm{~m}$ and sea level decrease relative to the ocean floor of about $102 \mathrm{~m}$ add up to a $156-\mathrm{m}$ increase of continent elevation over sea level since $65 \mathrm{Ma}$. Both are affected most strongly by the roughly $1.7 \%$ continent surface area decrease caused by Cenozoic mountain building. This includes contributions from erosion. Volumes of sediments in deltas and submarine fans indicate an average thickness of $371 \mathrm{~m}$ deposited globally in the ocean basins since $65 \mathrm{Ma}$. This relatively large change of continent area over a short span of Earth history has significant consequences. Extrapolating, if continent area change exceeded 5\% in the past, either severe erosion or flooded continents occurred. If continent elevation (freeboard) remains at the present value of a few hundred meters, the past continent-ocean area ratio might have been quite different, depending on earlier volumes of continental crust and water. We conclude that, along with the ages of ocean basins, continental crustal thickening exerts a first-order control on the global sea level over hundreds of million years.

Citation: Whitehead, J. A., and P. D. Clift (2009), Continent elevation, mountains, and erosion: Freeboard implications, J. Geophys. Res., 114, B05410, doi:10.1029/2008JB006176.

\section{Introduction}

[2] Mantle convection exhibits surface convergence at subduction zones. As a result, the flow relentlessly draws continents to these plate boundaries. Once continental material arrives, it tends to be thickened by the compressional forces of subduction and collision. Overall, in the vast majority of cases, the collision of continents with subduction zones leads to mountain building [Dewey and Bird, 1970; Yin and Harrison, 2000], but there are varying degrees of efficiency. Continent-continent collisions are particularly effective at thickening the continental crust, while thickening is thwarted by the retreat of subduction boundaries [Royden, 1993a]. Overall, it would seem that mountain building is the most efficient mechanism on Earth for thickening existing crust. Because known mountain chains date back to more than three billion years [Nisbet, 1987], thickening by orogeny may have been active throughout the history of the continents.

[3] Two processes, erosion and tectonic extension, actively decrease the thickness of continental crust. Subaerial erosion is particularly efficient at reducing elevated terrain. The bulk of continental elevation lies within just a

\footnotetext{
${ }^{1}$ Department of Physical Oceanography, Woods Hole Oceanographic Institution, Woods Hole, Massachusetts, USA.

${ }^{2}$ Department of Geology and Petroleum Geology, School of Geosciences, University of Aberdeen, Aberdeen, UK.
}

Copyright 2009 by the American Geophysical Union. 0148-0227/09/2008JB006176\$09.00 few hundred meters above sea level, and most of Earth's water is in the ocean basins, a relationship known as the freeboard effect [Wise, 1974; Harrison, 1998, 1999; Hynes, 2001; McElroy and Wilkinson, 2005]. According to known formulas of subaerial erosion, which depend primarily on continent surface slope, the time required for such erosion to significantly degrade new mountain belts is only a few hundred million years [Zhang, 2005], a value in agreement with geological field evidence [Veizer and Jansen, 1985; Clift et al., 2009].

[4] In addition, continental crust is thinned by extension of the crust after mountain building episodes [Wang et al., 2001; Kaufman and Royden, 1994]. This includes many alterations to the orogens [Huerta et al., 1998, 1999], including thermal processes [Royden, 1993b; Huerta et al., 1996], internal deformation, particularly after active mountain building events [Thatcher et al., 1999], lower crustal and lithosphere delamination [Bird, 1979; Kay and Kay, 1993] and instability at the base of the crust [Conrad and Molnar, 1997; Houseman and Molnar, 1997]. Extension measured by global positioning has been used along with a hydrostatic approximation to estimate the viscosity of the continental material in the orogens [England and Molnar, 1997; Flesch et al., 2000].

[5] The freeboard concept indicates that erosion might dominate over the other alteration processes in causing old mountain belt crustal thicknesses to approach the equilibrium values of the continent, and for the mean continent elevation to slightly exceed the ocean surface. Over the age of Earth, 


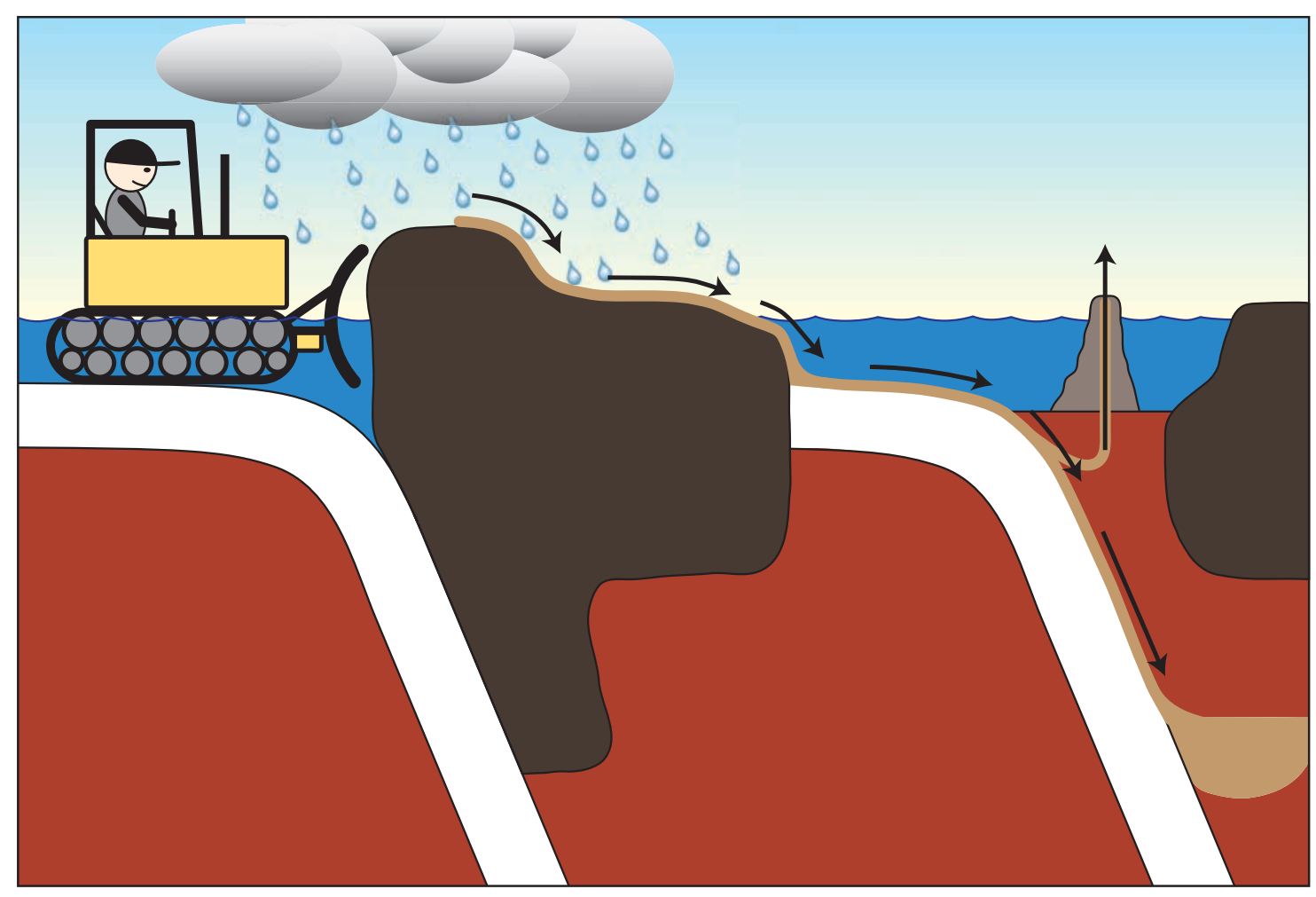

Figure 1. Mantle convergence by mantle convection thickens the crust, which is balanced by erosion and return of crustal material to the mantle, thus forming a cistern holding Earth's water.

the combination of crustal thickening from convergence of continent material to an average thickness of about $38 \mathrm{~km}$ [Christensen and Mooney, 1995] and subaerial erosion has lead to the well-known bimodal distribution of elevation of Earth. We illustrate these two processes in a cartoon (Figure 1) with mantle convergence thickening the crust and with erosion by water flattening the continents and then sweeping material into the oceans, where subduction ultimately carries it down into Earth's interior. Although the freeboard concept explains that the continental land elevation is mostly just above the ocean surface, the same processes in conjunction with crustal thickening from mantle convection/mountain building also enable the ocean area to be continually altered such that Earth's water almost perfectly fits into its own cistern (the ocean).

[6] The purpose of this study is to present a method to quantify the relation between mean continental crustal thickness and sea level independent of other potential controls, which have been addressed in detail in the past [e.g., Müller et al., 2008]. Therefore, in this paper, we quantify only the dual effects of crustal thickening and the counteracting effects of erosion. The analysis covers the past 65 million years, so that we may assume volumes of continental crust and water to have been relatively constant. Following the works of Harrison [1999] and Hynes [2001], but in contrast to many of the other estimates of freeboard published to date [Wise, 1974; Reymer and Schubert, 1984; Schubert and Reymer, 1985; Harrison, 1994; Lowman and Jarvis, 1995; Zhang, 2005], in this study the continent and ocean areas are allowed to change. Unlike all earlier works, we focus upon the variation of the thickness of the continental crust. The resulting variation of the areas of the continents and ocean produces sea level changes, which is a control not previously recognized or quantified.

[7] First, we determine changes in crustal thickness (section 2), then the amount of eroded material (section 3) since $65 \mathrm{Ma}$. These allow the calculation of changes in elevation (which are $\sim 150 \mathrm{~m}$ ) for both mean continent elevation and sea surface elevation relative to the ocean floor (section 4). The intent is not to reproduce in detail the change in sea level from all factors between now and $65 \mathrm{Ma}$, but to illustrate and quantify at two times (the present and at $65 \mathrm{Ma}$ ) the effects from the two primary factors-mountain building and erosion-leading to freeboard. In this way, we make a first attempt at quantifying the balances that lead to freeboard variations through time. Our estimates of ocean area changes are somewhat greater but in the same direction as estimates of the change of ocean area by Müller et al. [2008] by the independent technique of reconstruction of ocean basins. Finally, the possible range of errors and the implications of the trends if they are interpolated further back in time are discussed (section 5).

\section{Determination of Crustal Thickness}

[8] In this section, we estimate the change in crustal thickness and area of the continents for a given period of time. In order to see how Cenozoic orogenesis may have influenced global sea levels and continental freeboard, we choose to compare modern Earth, which is in a particularly active orogenic state, with one in which there were fewer and less extensive major mountain belts. We choose $65 \mathrm{Ma}$ at the end of the Cretaceous as just such a time because this predates the India-Asia collision, which is arguably the 

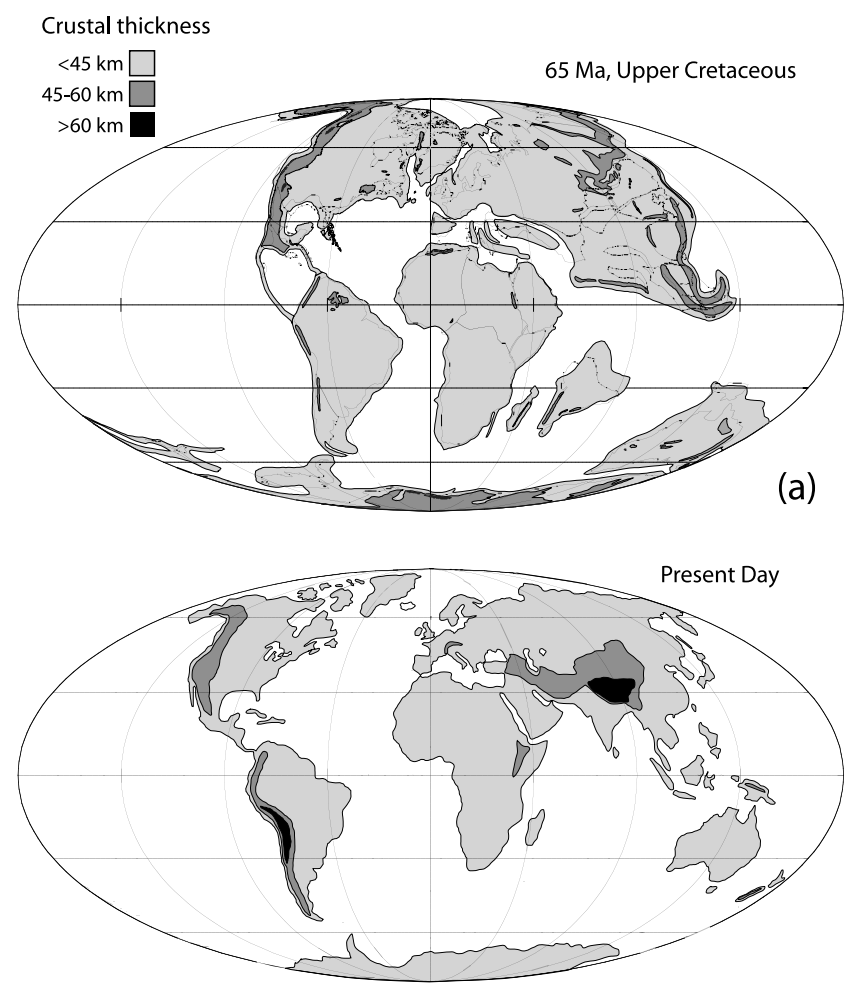

(b)

Figure 2. Continent crust thickness distribution at (a) $65 \mathrm{Ma}$ and (b) present.

largest orogen since the Pan-African $\sim 600 \mathrm{Ma}[$ Deynoux et al., 2006; Yoshida, 2007], as well as major plateau building in the Andes and in eastern Anatolia. Although subduction zones and their associated arcs were present in the Late Cretaceous, especially along the southern edge of Eurasia [Sengor, 1984; Dercourt et al., 1986], only in western North America do we see suggestions of larger mountains and development of a limited plateau whose collapse after the Laramide Orogeny resulted in the extension of the Basin and Range Province [DeCelles et al., 1987; McMillan et al., 2006]. Clearly major topographic uplift in central Asia postdates the India-Asia collision, which despite some controversy is agreed to be Cenozoic in age [Aitchison et al., 2007; Rowley, 1996]. The timing and extent of major topographic uplift of the Altiplano Plateau is also a source of debate, and is variously constrained as being post- $10 \mathrm{Ma}$ [Ghosh et al., 2006] or $>20$ Ma [Hartley et al., 2007]. Collision between Arabia and Eurasia is generally dated in the Oligocene to Early Miocene, 30-25 Ma [Saintot et al., 2006; Vincent et al., 2007]. Regardless, it is clear that many of the major modern mountain chains are Cenozoic features.

[9] In order to calculate the effect of greater degrees of continental thickening and also increased erosion on the ocean basins it is necessary to know the areas of normal and thickened crust at $65 \mathrm{Ma}$ and in the present day, i.e., the extent to which mountain belts are more extensive in the modern Earth relative to regular continental crust and to the oceans. In this, we assume a constant surface area for the entire Earth and a constant volume of seawater. Although there are some seismic data that constrain crustal thicknesses locally, these are not yet approaching global cover- age and they are, of course, not feasible for the $65 \mathrm{Ma}$ Earth. Therefore, we generate a rough estimate of global crustal thicknesses on the basis of topography, which is well known, and a simple isostatic assumption, i.e., that thick crust tends to generate higher mountains than thin crust. Seismology has shown us that average stable, continental crust has a thickness of $\sim 38 \mathrm{~km}$ [Christensen and Mooney, $1995]$ and that crust now at sea level averages $\sim 35 \mathrm{~km}$ thickness. We estimate the proportions of crust in three different groups: first, those $<42.5 \mathrm{~km}$, second, those $42.5-$ $58 \mathrm{~km}$ thick, and third, those $>58 \mathrm{~km}$ thick, the latter representing the most dramatic orogenic plateaus. The thickest category is almost completely contained within the Tibetan Plateau and the Andean Altiplano. The Rockies contribute much less than one percent and the Alps virtually nothing. Using an average continental crustal density of $2800 \mathrm{~kg} / \mathrm{m}^{3}$ and mantle density of $3300 \mathrm{~kg} / \mathrm{m}^{3}$ (in this paper, we simply use textbook values for densities of crust, mantle and ocean water from Turcotte and Schubert [2002]) we estimate that $42.5-\mathrm{km}$-thick crust stands at $\sim 1.5 \mathrm{~km}$ elevation above modern sea level, while $58-\mathrm{km}$-thick crust rises to $3.8 \mathrm{~km}$. Thus, by measuring the areas in maps like those shown in Figure 2 of crust lying between the continent-ocean boundaries, $1.5 \mathrm{~km}$, and $3.8 \mathrm{~km}$ elevation, we can achieve a rapid estimate of the global crustal thickness distribution. Although finer thickness resolution would be possible with more categories of crust or use of gravity data, our purpose here is to generate a first-order estimate of crustal state, which can be compared with the 65 Ma Earth and then to use this to assess the possible influence of enhanced orogenesis and erosion on sea level.

[10] Two areas of high elevation are generally recognized as having normal crustal thicknesses but are elevated because of large-scale mantle thermal anomalies, i.e., the Ethiopian hot spot and the Basin and Range province of western North America. These represent 3.5 and 4.0\% respectively of the $42.5-58.0 \mathrm{~km}$ thick crustal class and we adjust for these accordingly. Although we do not include Greenland and Antarctica in our estimates because elevations there are enhanced by ice, we set their thickness equal to the thickness of standard crust both for the modern Earth and at $65 \mathrm{Ma}$.

[11] Determining the topography at $65 \mathrm{Ma}$ is clearly much harder to do compared to the modern state and so we rely on paleogeographic reconstructions, particularly that of Patzkowsky et al. [1991], on the basis of an array of sedimentary and paleontological proxies. This reconstruction differs in moderate ways from alternatives [e.g., Scotese, 1991; Dercourt et al., 1993], but may be considered as a fairly standard description of Earth's geography at that time. Clearly accurate determination of paleoaltitude even locally is very hard to do and our $65 \mathrm{Ma}$ model cannot be considered to be very well constrained in this respect. The elevated regions shown on the 65 Ma reconstruction are fold belts active at that time and which Patzkowsky et al. [1991] and we presume to have thicker than normal crust, i.e., in the $42.5-58 \mathrm{~km}$ range. The only crust $>58 \mathrm{~km}$ thick is defined from the very largest mountains in western North America, on the basis of petrological evidence for very thick crust, and the tectonic evidence for subsequent gravitational collapse. We do not suggest that the Patzkowsky et al. [1991] altitude map for $65 \mathrm{Ma}$ is perfect, but rather that it 
Table 1. Percentage of Earth Covered by Different Crustal Thickness Groups

\begin{tabular}{lll}
\hline Crustal Thickness & $65 \mathrm{ma}$ & Present \\
\hline $58(70)$ & $0.1 \%$ & $1.8 \%$ \\
$42.5-58(50.25)$ & $7.5 \%$ & $10 \%$ \\
$<42.5(36)$ & $92.4 \%$ & $88.2 \%$ \\
& & \\
Average thickness & 37.103 & 38.037 \\
\hline
\end{tabular}

is a plausible and reasonable approximation for the end Cretaceous and that there is little or no evidence for extensive high plateaus of Tibetan/Altiplano style. The resulting distributions of the three thickness classes on Earth at $65 \mathrm{Ma}$ are also shown in Figure 2.

[12] Naturally, any detailed reconstruction of crustal thickness from elevation will contain some error because it is well known that Moho depth, which is frequently interpreted as crustal depth, does not perfectly correlate with elevation. Many questions remain of this interpretation of the Moho, at least in detail [Griffin and O'Reilly, 1987]. In particular, areas underlain by hotter than normal asthenosphere are more elevated than normal for their crustal thickness. As noted above, the two principle areas that affect this study are the American Basin and Range [Huerta et al., 1996] and the region of the Ethiopian hot spot as well as parts of southern Africa [Burke, 1996; Lithgow-Bertelloni and Silver, 1998] and these have been accounted for in our analysis. Other regions have decreased elevation compared to crustal thickness. A deviation of New Jersey sea level of about $150 \mathrm{~m}$, for example is attributed to the Farallon slab under North America [Müller et al. 2008]. However, these localized effects are ignored in this study because to a first approximation on a global basis uplifted regions correlate positively with thickened crust. Therefore, the possible effects of mantle dynamic support can be accounted for by using appropriate uncertainties.

[13] On the basis of this analysis, the areas of the three crustal thickness classes are given in Table 1. We round off the area of Earth to $510 \times 10^{6} \mathrm{~km}^{2}$ and the area of the present continents (including flooded portions) to $200 \times 10^{6} \mathrm{~km}^{2}$. Therefore, at present about $3.6 \times 10^{6} \mathrm{~km}^{2}(1.8 \%)$ of the present continents have young, high mountain belts that are assigned a crust with a thickness of $>58 \mathrm{~km}$. About $20 \times$ $10^{6} \mathrm{~km}^{2}(10 \%)$ of the present continents have less elevated regions that are still clearly uplifted. These are assigned a thickness of $50.25 \mathrm{~km}$, the average thickness of the 58 $42.5 \mathrm{~km}$ thick crust. The remaining $176.4 \times 10^{6} \mathrm{~km}^{2}$ $(88.2 \%)$ of present surface area of the continents are assigned a typical midcontinent thickness of $36 \mathrm{~km}$. We call this "old crust." The three classes combined have an average global crustal thickness at present of $38.037 \mathrm{~km}$.

[14] To a first approximation, the crustal thicknesses of the Tibetan Plateau and the Andean Altiplano are well constrained and there is little room for doubt about the surface area for the class of thickest crust. However, for crust that is $42.5-58 \mathrm{~km}$ thick, our estimate of $10 \%$ might be high because of influence from Ethiopia and the Basin and Range, with $8 \%$ of continental area being a possible minimum. This uncertainly is quantified in section 5. The numbers are quite different at $65 \mathrm{Ma}$, being $0.1 \%$ for high mountains, $7.5 \%$ for less elevated uplifted regions with the $42.5-58 \mathrm{~km}$ thickness class and $92.4 \%$ for average thick- ness of $36 \mathrm{~km}$. These produce an average crustal thickness of $37.103 \mathrm{~km}$ at $65 \mathrm{Ma}$. In this model, the greater areas of thickened crust at present have been produced by tectonic forces associated with convergence of preexisting material and not substantially by the production of new material through igneous processes. While most new crust is generated in magmatic arcs [Rudnick 1995], continent-continent collision zones appear to be largely regions of crustal reworking. Our next task is to calculate the continental area $(A)$ at $65 \mathrm{Ma}$. However, before this is done the amount of sediment removed by erosion must be estimated.

\section{Sediment Flux Rates}

[15] The excess material eroded and placed on the ocean floor since $65 \mathrm{Ma}$ as a result of uplift driven by tectonic activity must be estimated to derive an accurate crustal budget. We assume that the normal flux of sediment from old continent to ocean floor to subduction regions is in steady state, with no gain or loss to the ocean floor. The proportion of sediment that is off-scraped in subduction accretionary wedges is a small proportion of the total $(\sim 15 \%)$ [Clift and Vannucchi, 2004]. In addition, subducted sediment is largely returned to the mantle [Vannucchi et al., 2008] and thus leaves the domain of this study This means that $\sim 70 \%$ of continental sediment entering subduction zones is recycled to the mantle. In order to determine the long-term rates of erosion on the continents and the volumes of sediment exported to the ocean basins, we focus on the Cenozoic because over this time period we have reasonable structural and age control on continental margin sediment masses, at least for a number of the world's major river systems. It is only sediment eroded and deposited in the ocean basins that is significant for understanding the effect on sea level, rather than sediment deposited in terrestrial basins. Because it is not practical to directly measure the total global volume of Cenozoic sediment we make longterm, Cenozoic erosion budgets for a number of major drainages and then extrapolate these results to those parts of the world where surveying is insufficient to generate reliable records. Figure 3 shows a map with those drainages considered and the regions of major Cenozoic mountain building.

[16] Eroded rock volumes are calculated from the volumes of sedimentary rock using a suitable porosity correction estimate, which depends on the total thickness of sediment [Sclater and Christie, 1980]. For most sections $>5 \mathrm{~km}$ a $20 \%$ porosity value is a reasonable approximation for the entire pile [Johnson, 1994]. We also make a correction for major carbonate masses, although close to the deltas of major rivers this is rarely a significant issue within the errors of the general estimate. In some delta and submarine fan systems significant seismic imaging has been collected and detailed sediment volume estimates already made (e.g., many of the Asian delta systems [see Clift et al., 2004b; Métivier et al., 1999]). In these cases, we simply use the published volumes for Cenozoic sediment masses. However, in other systems we have had to make our own volume approximation. In those cases (e.g., the Nile), we use long, regional seismically based cross sections that have been converted from time to depth. This allows the crosssectional area of sediment, dated as being Cenozoic, to be 


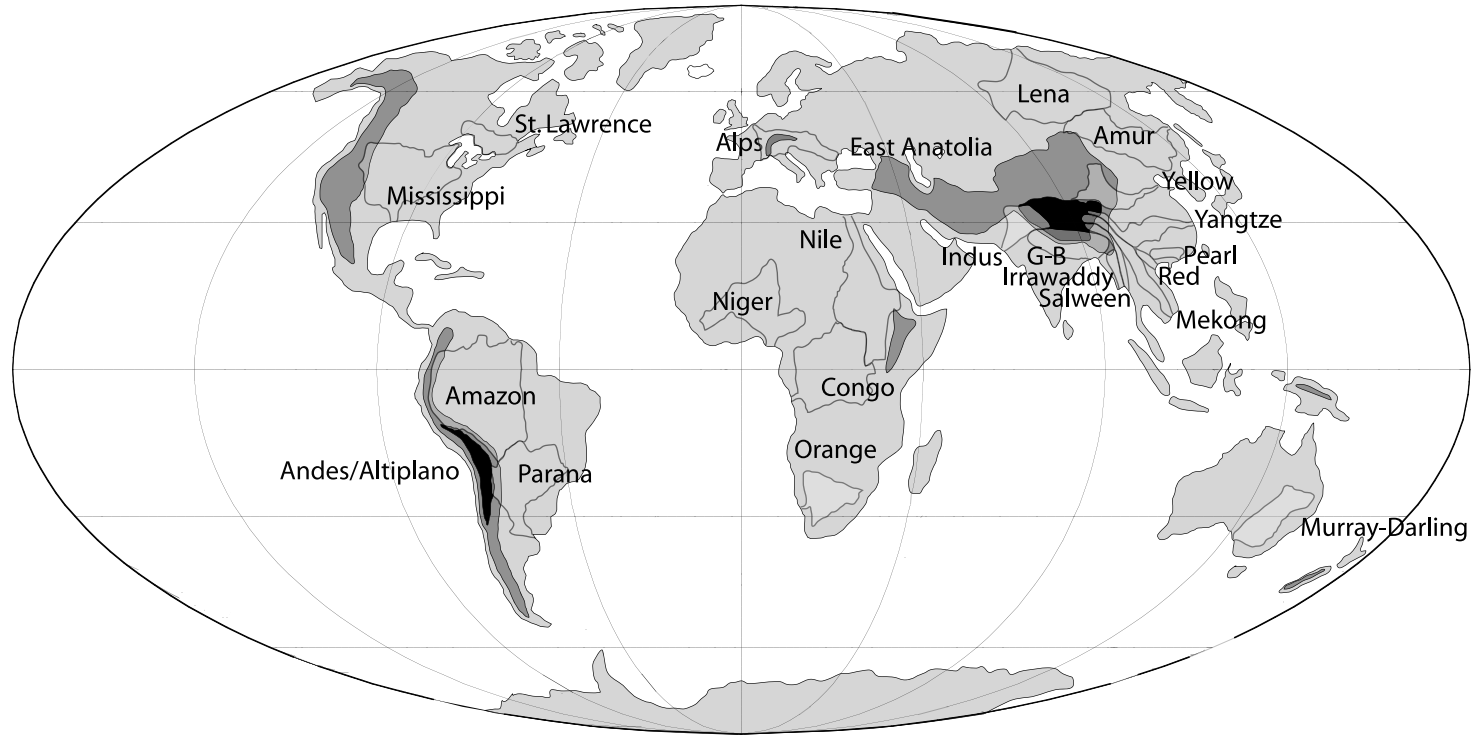

Figure 3. River drainage regions.

determined. If more than one regional-scale section can be found, then these were combined to improve the average estimate. The emphasis was on long, regional-scale lines rather than detailed shorter lines because these provide a poor image of sediment storage across an entire continental margin. Depending on sea level or tectonic subsidence patterns, sediment may be stored in different parts of the fan-delta at different times, meaning that only regional-scale profiles provide reliable sediment budgets. The width of the fan, or its radius, depending on the geometry of the system, is then used to calculate an estimate of the total volume of sediment in the submarine fan. Although the list of rivers is not exhaustive, constrained mostly by lack of published offshore sedimentary data, we have attempted to include rivers from all continents and spanning several climate zones.

[17] As has been widely recognized and confirmed here, erosion rates in areas of significant topographic relief (generally $>1 \mathrm{~km}$ of local relief) are subject to much faster physical erosion than low-lying, tectonically passive areas [Milliman and Syvitski, 1992]. As a general rule those regions affected by Cenozoic orogenesis have been regions of faster erosion during that period, while stable cratonic regions have eroded more slowly. The average depth of erosion calculated for each basin has no physical reality because sediment is typically generated in small parts of any given basin at any one time rather than evenly across the whole area. However, for the purpose of our study we simply derive an average basin-wide rate. For rivers draining Cenozoic mountains we presume the sediment has been eroded from the mountains and not the floodplain, a simplification on the basis of several provenance studies [Copeland et al., 1990; Clift et al., 2004a]. Even in the mountains themselves it is recognized that some regions are much more productive of sediment than others [Stewart et al., 2008], usually reflecting climatic factors. Indeed the high plateaus of Tibet and the Altiplano are characterized by very low erosion and sediment production rates because they are dry regions and the centers of the plateaus no longer experience rapid rock uplift. In these regions it is the edges of the plateaus that generate much of the sediment flux. The net export of rock from source to ocean may also be reduced if there are major sedimentary basins within the continents that prevent loss of continental crust to the ocean basins. This is the case in the Andean foreland basin, which is volumetrically similar to the Amazon Fan $(1,347,500$ versus $1,858,602 \mathrm{~km}^{3}$; see Table 2). In addition, southern and eastern Africa are elevated because of mantle upwelling and rifting processes respectively rather than plate collision and orogenesis, but are nevertheless elevated and subject to faster erosion rates.

[18] In order to generate a global erosion estimate, we split the continental regions into two groups, "elevated, orogenic" and "low lying, stable," which we estimate to account for $17 \%$ and $83 \%$ respectively of the currently exposed continental area (Table 2). There is no need to estimate erosion in detail for the three crust thickness classes of section 2. We then assign each of the rivers

Table 2. Sizes of Sediments, Continents, and Crust

\begin{tabular}{|c|c|c|}
\hline & Measured & Projected \\
\hline \multicolumn{3}{|l|}{ Stable Crust } \\
\hline Total drained area $\left(\mathrm{km}^{2}\right)$ & $22,089,000$ & $123,710,000$ \\
\hline Total eroded volume since $65 \mathrm{Ma}\left(\mathrm{km}^{3}\right)$ & $7,570,200$ & $42,396,800$ \\
\hline Average depth eroded since $65 \mathrm{Ma}(\mathrm{km})$ & 0.34 & \\
\hline \multicolumn{3}{|l|}{ Orogenic } \\
\hline Total drained area $\left(\mathrm{km}^{2}\right)$ & $6,831,935$ & $24,719,413$ \\
\hline Total eroded volume since $65 \mathrm{Ma}\left(\mathrm{km}^{3}\right)$ & $20,050,428$ & $72,546,772$ \\
\hline Depth eroded since $65 \mathrm{Ma}(\mathrm{km})$ & 2.93 & \\
\hline \multicolumn{3}{|l|}{ Global } \\
\hline Area of modern continents $\left(\mathrm{km}^{2}\right)$ & $148,429,000$ & \\
\hline Area of Cenozoic mountains $\left(\mathrm{km}^{2}\right)$ & $24,719,400$ & $17 \%$ \\
\hline Area of stable crust $\left(\mathrm{km}^{2}\right)$ & $123,709,600$ & $83 \%$ \\
\hline Average depth eroded since $65 \mathrm{Ma}(\mathrm{km})$ & 0.77 & \\
\hline
\end{tabular}




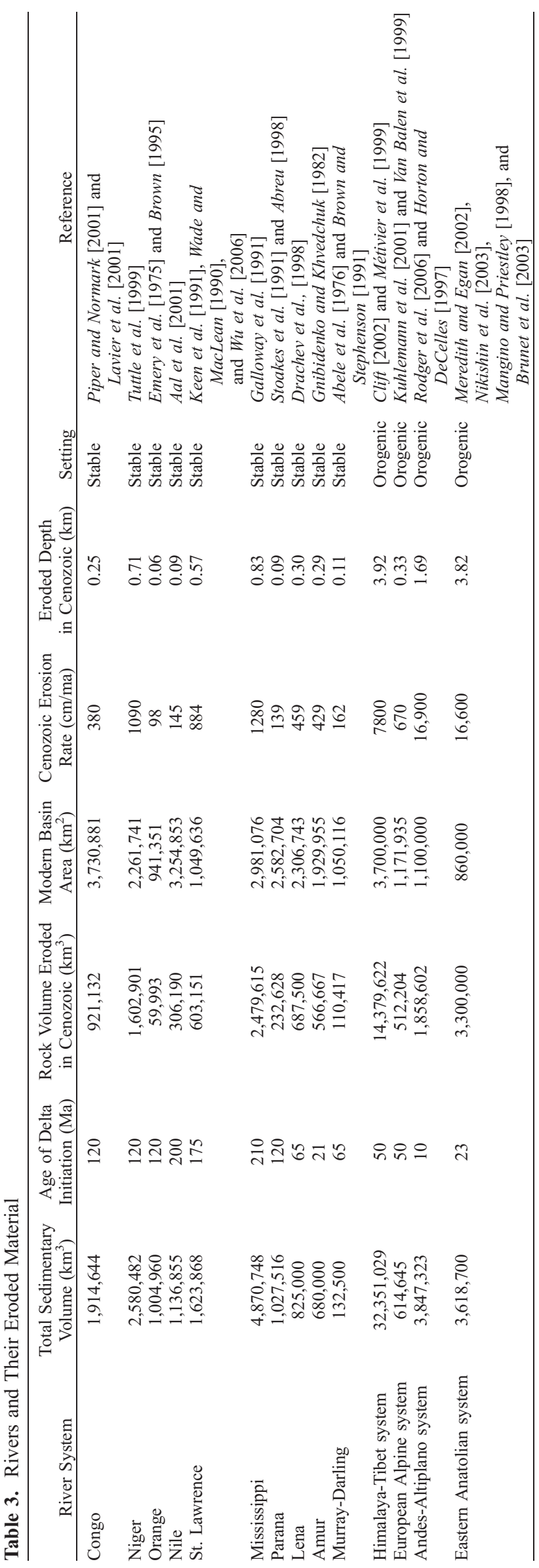

considered to one of these groups (Table 3). Although major rivers usually derive runoff from both orogenic and stable regions, we assign a river to the orogenic grouping if there is significant erosion from Cenozoic mountain sources. We calculate long-term Cenozoic erosion rate estimates for four of the most significant and well documented continental collision zones, the Himalaya-Tibetan Plateau, the Altiplano Plateau/central Andes, eastern Anatolia (Arabia-Eurasian collision zone), as well as the European Alps, which although much smaller than the other systems is particularly well surveyed, allowing accurate estimates of the erosion rates to be derived. In each of these cases the total amount of sediment exported to the ocean floor can be compared with the area of the sources within the basins to estimate longterm erosion rates over the entire orogen, while recognizing that in reality sediment is often mostly generated from limited parts of the belt.

[19] In order to derive a global erosion estimate we add together the Cenozoic eroded masses delivered by rivers draining stable regions and divide this value by the total area of those drainage basins. This gives us an average Cenozoic erosion rate for these river basins. In the absence of other data we assume that other areas of the stable continental crust also erode at these rates and so we extrapolate our estimates to Earth's entire surface that was not tectonized in the Cenozoic. Similarly, we determine an average erosion rate for those areas of Earth that are affected by Cenozoic orogeny and faster erosion (totaling $\sim 17 \%$ of the total continental area) by comparing the volumes of sediment with the area of the mountainous source regions in the region surveyed. We derive a separate estimate for these areas and likewise extrapolate our results to all Cenozoic mountainous regions. Combination of the two yields an estimate of how much sediment has been exported to the global ocean from the continents by rivers in the Cenozoic.

[20] In the case of the orogenic plateaus we consider the Cenozoic sediment masses in all the surrounding oceanic basins, even when major rivers are not involved. By estimating the volumes of sediment in the major oceanic depocenters we can calculate the long-term erosion rates and therefore how much of the "excess crust" is exported to the ocean basins rather than being re-distributed within continental depocenters. For example this means that in eastern Anatolia we consider the sediment in the southern Caspian Sea and the eastern Black Sea, east of the Mid Black Sea Ridge, but not in the Mesopotamian foreland, which is still within continental crust and is effectively only redistributed crust. The total eroded sediment that has been placed on the ocean floor is summed up and used to estimate the global volumes of eroded rock by extrapolation.

[21] Since we only considered $22,089,000 \mathrm{~km}^{2}$ of stable basin area while there is actually $123,710,000 \mathrm{~km}^{2}$ of that terrain, we prorated the eroded volume from the regions that are constrained. The result is that we predict that all the stable continents in the studied regions have lost an average of $340 \mathrm{~m}$. The same was done with the mountains but in this case we measured $6,830,000 \mathrm{~km}^{2}$ compared to a global total of $24,719,400 \mathrm{~km}^{2}$ and prorated accordingly. Totaling everything up, we estimate a total Cenozoic eroded volume of $114,943,500 \mathrm{~km}^{3}$, exported at 

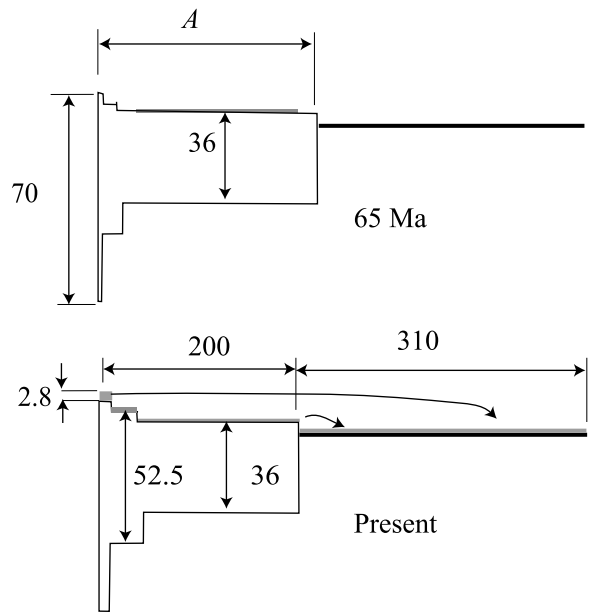

Figure 4. Schematic representation of the area and thickness of sections of the continents and of the oceans. The three crustal thickness classes are shown, and the width of each class shows qualitatively the area of each class. (a) At $65 \mathrm{Ma}$ the thickest crust class with thickness of $70 \mathrm{~km}$ has a very small area. (b) At present the thickest class of crust is $1.8 \%$ of the area of the continents, the intermediate class is $10 \%$, and the thinnest is the remainder. Also, the top surface of these two classes is eroded away along with erosion of the thinnest class and deposited into the oceans.

a long-term rate of $1.76 \mathrm{~km}^{3} \mathrm{a}^{-1}$. Adding them together results in the $770 \mathrm{~m}$ global average of material removed from the projected area in Table 3 . Note however that the total of both projected areas is $174,593,600 \mathrm{~km}^{2}$ but the entire area of continents, which is rounded off to $200 \times 10^{6} \mathrm{~km}^{2}$ as discussed in section 1, includes continental shelves, ice covered regions and some isolated desert basins. These have much smaller (and not included) rates of sediment export to the ocean floor. Using the rounded off ocean area of $310 \times$ $10^{6} \mathrm{~km}^{2}$, the sediment laid down on the ocean floor has average thickness given by the above volume of sediments divided by ocean area. We will call this $d_{s}=371 \mathrm{~m}$.

[22] To prepare for calculating elevations in the next section, we represent the continent as one body (Figure 4) with the average thicknesses for the three regions that are listed in Table 1. The gray lines represent erosion from the continents and deposition on the ocean floor as a layer $371 \mathrm{~m}$ thick. The old parts of the continents (thickness < $45 \mathrm{~km}$ ) are assigned a thickness of $36 \mathrm{~km}$ both at present and at $65 \mathrm{Ma}$. The assumption is that, although the volumes of eroded materials from stable crust indicate an average erosion of $371 \mathrm{~m}$ of continental crust, which has been deposited onto the ocean floor, the old crust thickness remains stable, and any eroded material from cratonic areas deposited on the ocean floor is replaced on old crust by the same volume. There are two sources, first, addition of new crust estimated to be about $1 \mathrm{~km}^{3} \mathrm{a}^{-1}$ [Reymer and Schubert, 1984] and deposition of sediment from the orogenic regions onto the old regions. Therefore, in the absence of firm, opposing data, we specify that the stable crust remains $36 \mathrm{~km}$ thick. As for the present continents, as in section 1, the areas of Earth at $65 \mathrm{Ma}$ with moderate orogeny are assigned an average thickness of $52.5 \mathrm{~km}$ and the high plateaus (thickness $>60 \mathrm{~km}$ ) are assigned an average thickness of $70 \mathrm{~km}$. All are sketched in Figure 4.

\section{Hydrostatic Calculations}

[23] We recognize that changes in the mean depths of the ocean basins through time must have an impact on the global sea level [Pitman, 1978; Kominz, 1984]. Changes in global sea level over long periods of geologic time are well documented [Haq et al., 1987; Miller et al., 2005]. Most recently, Müller et al. [2008] proposed a $200 \mathrm{~m}$ mean deepening since $65 \mathrm{Ma}$. However, in many of these models the area and thickness of the continents were assumed to be steady state. This assumption is not used with our calculations. In fact, the following hydrostatic model calculation shows that the changes in area and crustal thicknesses produce a measurable difference in the relative elevation between continents and ocean (the "freeboard"). Consider the hydrostatic balance of the simple model of continents and ocean floor sketched in Figure 5. The average depth of the continents is $d_{c}$. The hydrostatic pressure at the base of the continents is matched to the pressure under the ocean at the same depth in the mantle. The pressure under the oceans at this depth is produced by the accumulation of ocean water of thickness $d_{o}$, sediment of thickness $d_{s}$, and mantle of thickness $d_{m}$.

[24] Using values of the density of ocean seawater equal to $\rho_{o}=1030 \mathrm{~kg} \mathrm{~m}^{-3}$, the densities of both continent material and sediment equal to $\rho_{c}=2800 \mathrm{~kg} \mathrm{~m}^{-3}$, and density of mantle equal to $\rho_{m}=3300 \mathrm{~kg} \mathrm{~m}^{-3}$, the hydrostatic pressure balance is

$$
2800 g d_{c}=1030 g d_{o}+2800 g d_{s}+3300 g d_{m}+3300 g C,
$$

in which $g$ is the acceleration of gravity and $C$ is a constant to be determined from present data. This constant represents all the internal structures of Earth left out of this model such as the presence of ocean crust, the oceanic and continental

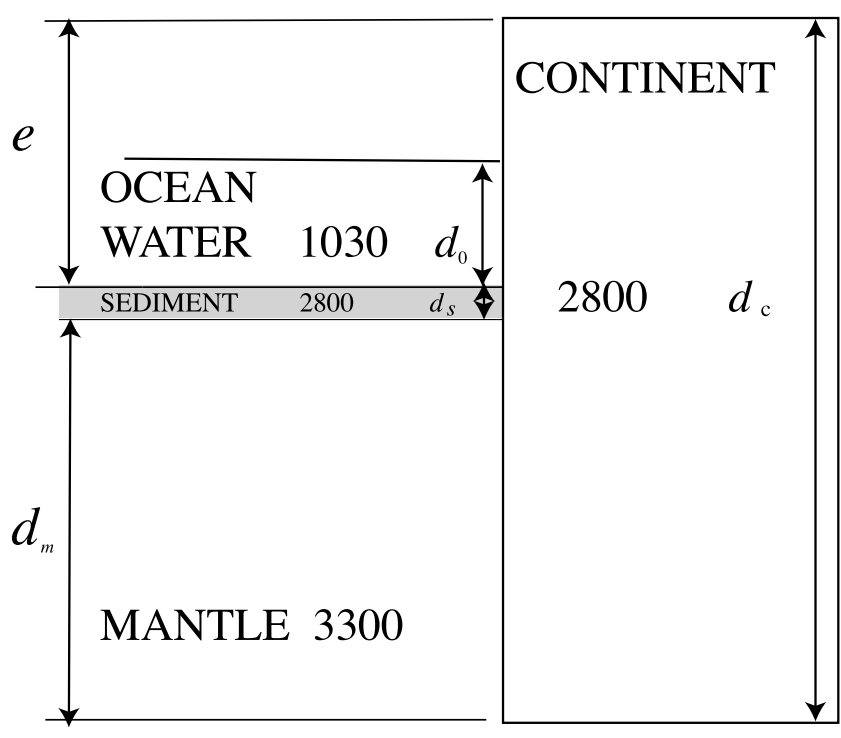

Figure 5. Hydrostatic model of the continents and oceans. The oceanic crust is the same in all models and absorbed into the constant $C$. 
lithospheres, internal variation within the continents, ocean ridges, and many other layers inside Earth. These internal structures clearly change with time [Müller et al., 2008] and make significant changes in sea level, but we neglect them and focus only on the effects of mountain building and erosion. Hence, $C$ is set to the same value. If the sediment on the ocean floor actually does not have the density assigned above, it does not matter because the mass of eroded material is really all that matters.

[25] Using $e+d_{s}+d_{m}=d_{c}$ to eliminate $d_{m}$, the elevation of the continents above the sediment surface is given by the formula

$$
e=\frac{3300-2800}{3300}\left(d_{c}-d_{s}\right)+\frac{1030}{3300} d_{o}+C .
$$

Values for the present Earth are used to determine $C$. The mean depth of the present oceans is the average water thickness, which is $d_{o}=3.800 \mathrm{~km}$ (ocean surface down to the top of the sediment). The value of average continent elevation above sea level at present is $0.835 \mathrm{~km}$. Both these values are from Turcotte and Schubert [2002]. These add up to a value of $e=4.635 \mathrm{~km}$. Using a value of $d_{c}=38.037 \mathrm{~km}$ for the average present continent crustal thickness from Table 1, a value of $d_{s}=0.371 \mathrm{~km}$ for the thickness of seafloor sediment from section 3 , and the ocean depth mentioned above, then $C=-2.2580 \mathrm{~km}$.

[26] Now, it is possible to calculate the value of elevation $e$ at $65 \mathrm{Ma}$ for comparison with the present value. We use the average value of the continental crustal thickness in Table 1 at $65 \mathrm{Ma}$ for this. The volume of continental crust at $65 \mathrm{Ma}$ was greater than at present, because it is equal to the volume of the present crust plus the additional amount that has been eroded from the land and deposited in the oceans as sediment over and above the sediments that were in the oceans at $65 \mathrm{Ma}$. These two add up to a crustal volume at $65 \mathrm{Ma}$ of $7.72241 \times 10^{9} \mathrm{~km}^{3}$. Dividing by the model thickness of $d_{c}=37.103 \mathrm{~km}$ at $65 \mathrm{Ma}$ indicates that the area of the continents $A_{c}$ at $65 \mathrm{Ma}$ was larger, with a value of $A_{c}=208.134 \times 10^{6} \mathrm{~km}^{2}$. As a result, the ocean area $A_{0}$ was reduced to a smaller area of $A_{0}=301.866 \times 10^{6} \mathrm{~km}^{2}$. The volume of seawater is assumed to have had only tiny changes and be conserved. (For example, the rates discussed by Harrison [1999] on the order of $10^{8} \mathrm{~km}^{3} \mathrm{Ga}^{-1}$ only change the volume by $1 / 2 \%$ in $65 \mathrm{Ma}$, equivalent to an ocean thickness change of $19 \mathrm{~m}$ ). Thus, the average ocean water depth at $65 \mathrm{Ma}$ is calculated to have been $d_{o}=$ $3.902 \mathrm{~km}$, a value $102 \mathrm{~m}$ greater than the present depth.

[27] Next, elevation of the continents at $65 \mathrm{Ma}$ is calculated. The sediment added to the ocean floor since $65 \mathrm{Ma}$ was not present then, so (2) with $d_{s}=0$ is

$$
e=\frac{3300-2800}{3300} d_{c}+\frac{1030}{3300} d_{o}-2.2580 .
$$

Using $d_{c}=37.103 \mathrm{~km}$, and $d_{o}=3.902 \mathrm{~km}$, the value of continent elevation $e$ at 65 Ma was $4.582 \mathrm{~km}$. Because average ocean water depth was $3.902 \mathrm{~km}$, this puts the average continent surface elevation $680 \mathrm{~m}$ above the sea surface, which is $155 \mathrm{~m}$ less than the present value of elevation of $835 \mathrm{~m}$, so that the average continent elevation relative to the sea surface is $155 \mathrm{~m}$ higher now than at
65 Ma. Clearly mountain building has increased continent elevation over the past $65 \mathrm{ma}$, although erosion has made some significant contribution at reducing the added elevation. This quantification of the two largest effects that have produced freeboard is consistent with the idea that the erosion timescale is hundreds of million years.

[28] Although a $155 \mathrm{~m}$ change in the elevation above sea level is an impressive figure, much of the added elevation is attributed to the added elevation of the mountains. To see this, the elevation of the thinnest class of the continental crust ("old crust" thickness $<45 \mathrm{~km}$ ) can also be calculated from equation (3). Using $d_{c}=36 \mathrm{~km}$, and $d_{o}=3.902 \mathrm{~km}$ at $65 \mathrm{Ma}$, we find that the elevation of the "old crust" was $e=$ 4.414, which was $512 \mathrm{~m}$ above the water surface. These values can be compared with the present elevation of crust with thickness $<45 \mathrm{k}$ using $d_{c}=36 \mathrm{~km}, d_{s}=0.371$, and $d_{o}=$ $3.8 \mathrm{~km}$ in equation (2), giving an elevation of $e=4.326 \mathrm{~km}$. Because water depth is $3800 \mathrm{~m}$ at present, the thin crust elevation is $526 \mathrm{~m}$ above the water surface. Therefore, thin crust elevation above the ocean surface (freeboard) at $65 \mathrm{Ma}$ was $512 \mathrm{~m}$ and at present it is $526 \mathrm{~m}$, so the present elevation level for "old crust" with respect to the sea surface is $14 \mathrm{~m}$ higher now than it was at $65 \mathrm{Ma}$.

[29] In summary, the nonthickened parts of the continent have experienced only small changes with respect to sea level in the past $65 \mathrm{Ma}$ but the thickened parts have experienced large changes. This is consistent with the postulated mechanism for freeboard: that mountain building is the principal mechanism of crustal thickening and it is also the primary mechanism for placing continent elevation above sea level. Erosion is the primary mechanism to bring high continent surfaces down toward sea level again.

\section{Discussion}

\subsection{Range of Errors}

[30] Numerous factors have been left out of these sea level calculations. These include the effects of ocean floor age, underlying slabs [Müller et al., 2008] and estimated vigor of mantle convection [Reymer and Schubert, 1984; Hynes, 2001]. Several such factors result in sea level changes on the order of 100-200 m. Here, we have focused on only the two mechanisms of crustal thickening and sediment removal from the continents. We estimate that the Tibetan Plateau and the Andean Altiplano are responsible for about $2 / 3$ of the signal from crustal thickening. There is little question of the value of the thickened crust of these two large plateaus [Yuan et al., 2002; Molnar, 1988] or of the timing of those mountain building events. An error estimate of the area and crustal thickness for the class with the greatest crustal thickness in Table 1 produced less than a $10 \%$ range of uncertainly. However, the remaining $1 / 3$ of the signal comes from the intermediate thickness, and the uncertainly is much greater there. First of all, half of the mountainous regions in Figure 2 are subject to interpretation concerning both their age and their size at $65 \mathrm{Ma}$ for which we follow the paleogeography of Patzkowsky et al. [1991]. Also, there is uncertainly about the presence of mantle thermal anomalies, about underlying slabs, about effects from the age of the crust and variations in elevation from variations in the underlying lithosphere, and about unaccounted and now subducted sediment deposits at $65 \mathrm{Ma}$. 
Table 4. Elevation Changes From $65 \mathrm{Ma}$ to Present

\begin{tabular}{ccccc}
\hline $\begin{array}{c}\text { Area Midrange } \\
\text { Crust }^{\mathrm{a}}(\%)\end{array}$ & $\begin{array}{c}\text { Crust } \\
\text { Thickness }^{\mathrm{b}}\end{array}$ & $\begin{array}{c}\text { Ocean } \\
\text { Depth } \delta d_{0}{ }^{\mathrm{c}}\end{array}$ & $\begin{array}{c}\text { Average } \\
\text { Elevation }^{\mathrm{d}}\end{array}$ & $\begin{array}{c}\text { Old } \\
\text { Elevation }^{\mathrm{e}}\end{array}$ \\
\hline 5 & 37.459 & -129 & 228 & 32 \\
7.5 & 37.103 & -102 & 155 & 14 \\
10 & 36.747 & -77 & 141 & -11 \\
\hline
\end{tabular}

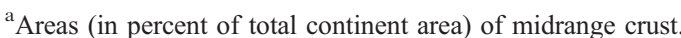

${ }^{\mathrm{b}}$ Average crustal thickness (in $\mathrm{km}$ ) $d_{c}$.

${ }^{\mathrm{c}}$ Change (in m) in ocean depth $\delta d_{0}=d_{0}(p)-d_{0}(65)$.

${ }^{\mathrm{d}}$ Change (in $\mathrm{m}$ ) in average continent elevation above sea level $e(p)-$ $d_{0}(p)-\left\{e(65)-d_{0}(65)\right\}$.

"Change (in $\mathrm{m}$ ) in "old crust" elevation above sea level $e(p)-d_{0}(p)-$ $\left\{e(65)-d_{0}(65)\right\}$.

Finally, even the true value of area of crust in the intermediate thickness range for the present Earth is not completely certain owing to the dynamic mantle thermal effects mentioned in previous sections. Therefore, the best way to quantify the consequences of such uncertainly is to pick two other values for the area of terrain in the $42.4-58 \mathrm{~km}$ range of thickness in Table 1 at $65 \mathrm{Ma}$. We have picked areas of $5 \%$ and $10 \%$ rather than $7.5 \%$, and then he have repeated the elevation calculations. The areas for the various classes for the present earth are kept the same as in Table 1, even though we emphasized in section 2 that those areas may be $1-2 \%$ too high in our present model.

[31] Taking first the lower value of $5 \%$, the average crustal thickness at $65 \mathrm{Ma}$ is $d_{c}=36.747 \mathrm{~km}$. This gives a continental area of $A_{c}=210.151 \mathrm{~km}^{2}$, an oceanic area of $A_{0}=299.849 \mathrm{~km}^{2}$, and water depth $d_{o}=3.929 \mathrm{~km}$, so the present ocean thickness is $129 \mathrm{~m}$ smaller. Then, using equation (3), the mean elevation at $65 \mathrm{Ma}$ is $e=4.536$ and this is $607 \mathrm{~m}$ above the sea surface. Therefore, the present mean continent elevation above the sea surface $(835 \mathrm{~m})$ is $228 \mathrm{~m}$ greater that the value for $65 \mathrm{Ma}(607)$. This change is $47 \%$ greater than the preferred estimate of $155 \mathrm{~m}$. Next, for the "old crust" we use $d_{c}=36 \mathrm{~km}$ and $d_{o}=3.929$ in equation 3 and find that the elevation above the seafloor was $e=4.423 \mathrm{~km}$, which is $494 \mathrm{~m}$ above the ocean surface (freeboard) at $65 \mathrm{Ma}$. Therefore, the present elevation of "old continent" (526 m) is $32 \mathrm{~m}$ higher than the sea surface at $65 \mathrm{Ma}$ with this $5 \%$ model.

[32] Next, the larger value of $10 \%$ will be used. The changes between $65 \mathrm{Ma}$ and present are due only to the high terrain of the Tibetan Plateau and the Andean Altiplano, whose elevations, crustal thicknesses and ages are basically unquestioned. The average crustal thickness at $65 \mathrm{Ma}$ is $d_{c}=37.459 \mathrm{~km}$. This gives a continental area of $A_{c}=$ $206.156 \mathrm{~km}^{2}$, an oceanic area of $A_{0}=303.844 \mathrm{~km}^{2}$, and water depth $d_{o}=3.877 \mathrm{~km}$, so the present value $(3.8 \mathrm{~km})$ of ocean thickness is $77 \mathrm{~m}$ smaller. Then, using equation (3), the mean elevation at $65 \mathrm{Ma}$ is $e=4.571$ and this is $694 \mathrm{~m}$ above the sea surface. Therefore, the present mean continent elevation above the sea surface $(835 \mathrm{~m})$ is $141 \mathrm{~m}$ greater than this. This change is $10 \%$ less than the preferred estimate of $155 \mathrm{~m}$. Next, for the "old crust" we use $d_{c}=36 \mathrm{~km}$ and $d_{o}=$ 3.877 in equation 3 and find that the elevation above the seafloor was $e=4.414 \mathrm{~km}$, which is $537 \mathrm{~m}$ above the ocean surface (freeboard) at $65 \mathrm{Ma}$. Therefore, the present elevation of "old continent" (526 m) is $11 \mathrm{~m}$ lower than the sea surface at $65 \mathrm{Ma}$ with this $10 \%$ model.

[33] The results for the three different crustal thickness models are summarized in Table 4. Clearly all three models have a significant change in mean ocean depth ranging from 77 to $129 \mathrm{~m}$, with our preferred model giving $102 \mathrm{~m}$. The change in mean continental elevation above the sea surface ranges from $141 \mathrm{~m}$ to $228 \mathrm{~m}$ with our preferred model giving $155 \mathrm{~m}$. The change in elevation above the sea surface of the thin class of crust ranges from -11 to $32 \mathrm{~m}$ with our preferred model giving $14 \mathrm{~m}$.

\subsection{Consequence of Constant Volumes of Crust and Water}

[34] If the volume of continental crust and of water is relatively constant through longer periods of geological time, there are a number of interesting consequences. The present volume of continental crust equals $V_{c}=7.679 \times 10^{9} \mathrm{~km}^{3}$. The ocean and continent areas add up to the surface area of Earth

$$
A_{o}+A_{c}=510 \times 10^{6} \mathrm{~km}^{2} .
$$

As before, we assume that at some past time the area $A_{c}$ of the continents was different and calculate the previous thickness of continental crust and the depth of ocean water. However, for the moment we ignore erosion and assume that the volume of continental material remains unchanged, and that water volume is also unchanged (the cyrosphere owing to ice ages is ignored). Therefore, the formulas for the thickness $d$ of crust (subscript $c$ ) and ocean water (subscript $o$ ) respectively are

$$
\begin{gathered}
d_{c}=V_{c} / A_{c} \\
\text { and } d_{o}=V_{o} / A_{o}
\end{gathered}
$$

where $V$ is the volume and $A$ is area. With all of these constraints, the values of elevation of the average continent surface above the seafloor $e$ is a function of the area percentage of Earth covered by continents, which we define as $x=A_{c} / 5.1 \times 10^{6}$. Using equation 3 , the values of elevation $e$, ocean depth $d_{o}$, and the thickness of the continental crust $d_{c}$ as functions of $x$ are shown in Figure 6.

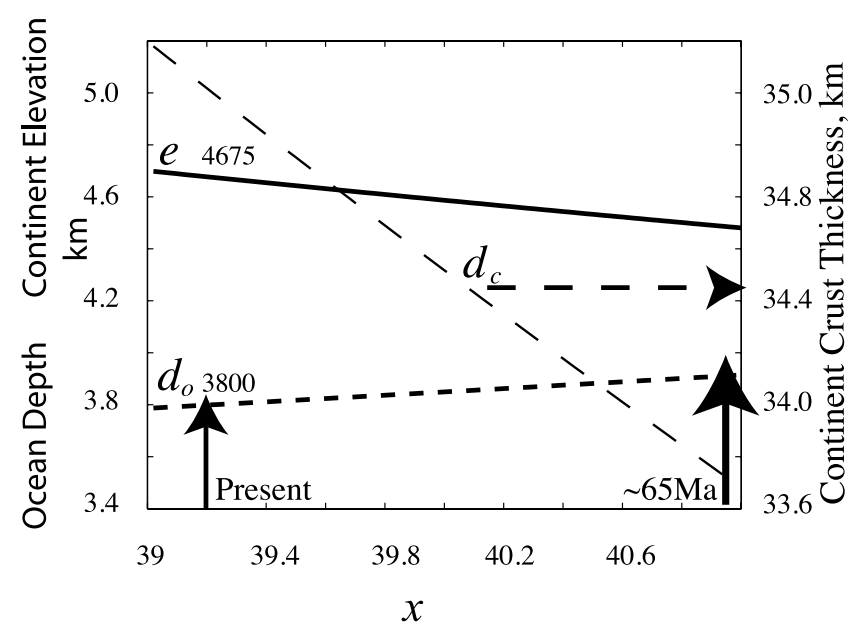

Figure 6. The mean elevation above ocean floor of the continents $e$, and the mean depth of the ocean $d_{o}$ (with the scale on the left) as a function of the percentage of Earth covered by continents. The thickness of continental crust $d_{c}$ uses the scale on the right. 


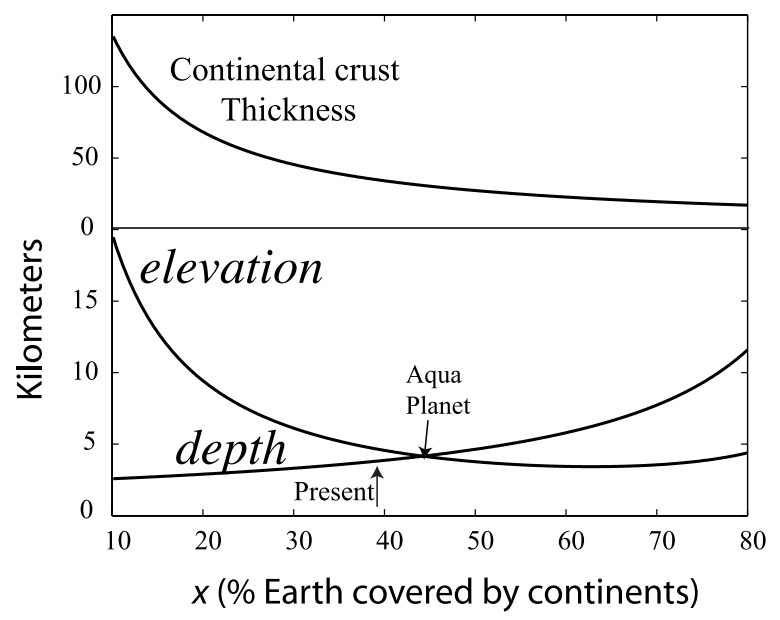

Figure 7. Mean continent elevation above the ocean floor and mean water depth as a function of continent area for present volumes of water and continental crust.

[35] As continent area increases, continental crustal thickness (hence the elevation) decreases and ocean depth increases. A gradual change in area with time can be quantified with a crude hypothetical timescale by recalling our estimates of crustal thickness change since $65 \mathrm{Ma}$ in which the decreased continent area is about $1.6 \%$ of the total area of Earth, as indicated by the arrow to the right in Figure 6. The increase of continent elevation above the ocean floor from $65 \mathrm{Ma}$ to present and the decrease of average ocean thickness are on the order of about $150 \mathrm{~m}$ and $100 \mathrm{~m}$ respectively. In spite of the fact that erosion is neglected, this is about the same size as the estimates made in section 4 .

[36] The sensitivity of elevation and sea level to the area of the continents is greater with the trends in Figure 6 plotted on a wider scale (Figure 7). We see that if one were to blindly extrapolate to an Earth with much larger continent surface area and use the timescale of $65 \mathrm{Ma}$ of a change of $1.7 \%$, then at roughly $200 \mathrm{Ma}$ all of the mean continent elevation could have been under the ocean surface and vast regions of the continents would have been submerged. This extrapolation is too extreme to be in accord with the presence of erosion and many other factors affecting sea level, of course, but noting that there are more than 50 known major orogenies in Earth history, Figure 7 shows that if continent area was greater in the past they would have been significantly flooded.

[37] In contrast, if there were circumstances in which the continents occupied a smaller area than now, then their average elevation would be high above the ocean surface. In an extreme case, if continents covered only $20 \%$ of Earth's surface, then the shelf break would be $2.4 \mathrm{~km}$ above sea level, and average continent elevation would be $3.4 \mathrm{~km}$ above sea level [Whitehead, 2003].

\subsection{Consequence of Constant Elevation/Freeboard}

[38] However, the freeboard concept, which we have attempted to quantify for $65 \mathrm{Ma}$, tends to rule out the extremes sketched in the previous section. Submerged orogenic belts would not erode; therefore collisions would tend to elevate the surface. Conversely highly elevated continents would erode quickly and elevation would be restored to present values. It is likely that the continents are restored to an elevation close to the present level of something like $1 \mathrm{~km}$ within one or two hundred million years [Clift et al., 2009]. The eroded sediment may even be restored to the continents when it is subducted at active margins. Melting of sediments in subduction zones is known to be an important contribution to magma production [Woodhead and Fraser, 1985; Plank and Langmuir, 1993] and in so doing the sediment is returned to the crust as part of new arc crust. However, a detailed budget to quantify the flux of continental crust into subduction zones and back to the surface by igneous processes does not presently exist.

[39] If one assumes that the forces of mountain building minus the effect of erosion would always limit the elevation of continents above the ocean surface to the present value $(835 \mathrm{~m})$, then one can calculate the area covered by continents if different volumes of continental crust and ocean water existed in the more distant past. Equations (3)-(6) are rearranged for this purpose to be

$$
\begin{aligned}
e-d_{o}+C & =3.137 \\
& =0.1515 \frac{V_{c}}{5.1 \times 10^{6} x}-0.688 \frac{V_{o}}{5.1 \times 10^{6}(100-x)} .
\end{aligned}
$$

The variable $x$ is the percentage of the planet covered by continents, and its contours are shown as a function of the volumes of continental crust and water in Figure 8. If the volumes of crust and water have been slowly changing throughout Earth history and the erosion-collision mechanics proposed here govern the continental crust thickness, then the surface of Earth that is covered by continents would travel over this plane and the continental area must have changed. This change would be accompanied by

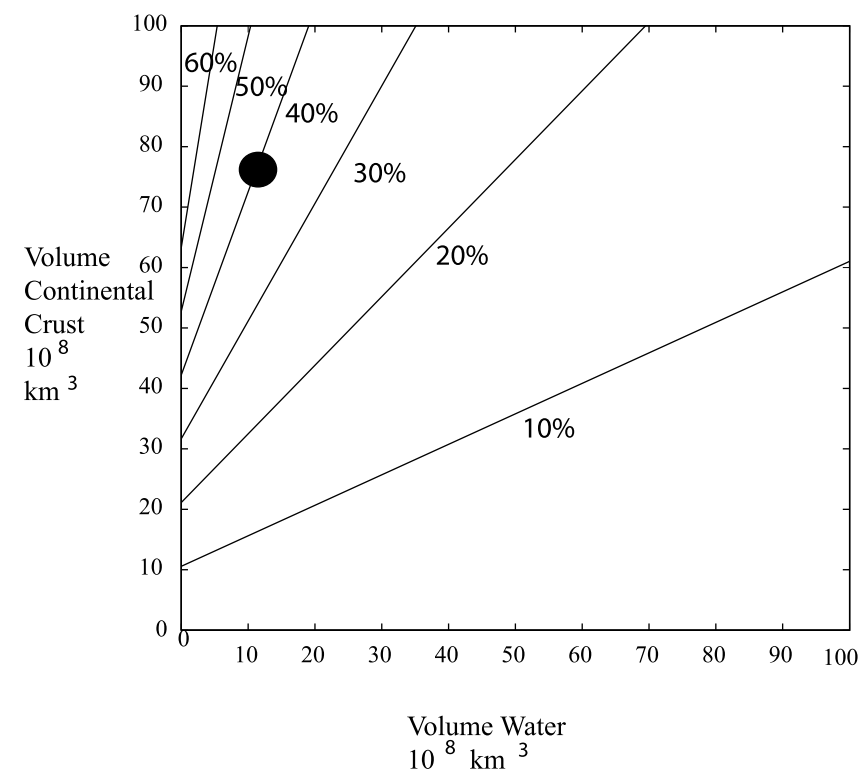

Figure 8. Contours of percentage of Earth covered by continent ( $10 \%$ increments) for a range of crust and water volumes. The present Earth is shown as a solid circle. 
change in both average ocean water thickness and continental crust thickness.

[40] Acknowledgment. The elevation calculations were suggested to J. Whitehead in a seminar by the Geodynamics Program at the Woods Hole Oceanographic Institution.

\section{References}

Aal, A. A., A. E. Barkooky, M. Gerrits, H.-J. Meyer, M. Schwander, and H. Zaki (2001), Tectonic evolution of the eastern Mediterranean Basin and its significance for the hydrocarbon prospectivity of the Nile Delta deepwater area, GeoArabia, 6, 363-384.

Abele, C., P. R. Kenley, G. Holdgate, and D. Ripper (1976), TertiaryOtway Basin, in Geology of Victoria, Spec. Publ., 5, edited by J. G. Douglas and J. A. Ferguson, pp. 198-229, Geol. Soc. of Aust., Sydney, NSW, Australia

Abreu, V. (1998), Geologic evolution of conjugate volcanic passive margins: Pelotas Basin (Brazil) and offshore Namibia (Africa), implication for global sea-level changes, Ph.D. thesis, 648 pp., Rice Univ., Houston, Tex

Aitchison, J. C., J. R. Ali, and A. M. Davis (2007), When and where did India and Asia collide?, J. Geophys. Res., 112, B05423, doi:10.1029/ 2006JB004706

Bird, P. (1979), Continental delamination and the Colorado Plateau, J. Geophys. Res., 84, 7561-7571.

Brown, C. M., and A. E. Stephenson (1991), Geology of the Murray Basin, Southeastern Australia, 430 pp., Bur. of Miner. Resour., Aust. Gov. Publ. Serv., Canberra, ACT.

Brown, L. F. (1995), Sequence Stratigraphy in Offshore South African Divergent Basins, 184 pp., Am. Assoc. of Petrol. Geol., Tulsa, Okla.

Brunet, M. F., M. V. Korotaev, A. V. Ershov, and A. M. Nikishin (2003), The South Caspian Basin: A review of its evolution from subsidence modelling, Sediment. Geol., 156, 119-148, doi:10.1016/S0037-0738 (02)00285-3.

Burke, K. (1996), The African Plate, S. Afr. J. Geol., 99(4), 341-409.

Christensen, N. I., and W. D. Mooney (1995), Seismic velocity structure and composition of the continental crust: A global view, J. Geophys. Res., 100, 9761-9788, doi:10.1029/95JB00259.

Clift, P. D. (2002), A brief history of the Indus River, Geol. Soc. Spec. Publ., 195, 237-258.

Clift, P. D., and P. Vannucchi (2004), Controls on tectonic accretion versus erosion in subduction zones: Implications for the origin and recycling of the continental crust, Rev. Geophys., 42, RG2001, doi:10.1029/ 2003RG000127.

Clift, P. D., I. H. Campbell, M. S. Pringle, A. Carter, X. Zhang, K. V. Hodges, A. A. Khan, and C. M. Allen (2004a), Thermochronology of the modern Indus River bedload: New insight into the controls on the marine stratigraphic record, Tectonics, 23, TC5013, doi:10.1029/ 2003TC001559

Clift, P. D., G. D. Layne, and J. Blusztajn (2004b), Marine sedimentary evidence for monsoon strengthening, Tibetan uplift, and drainage evolution in east Asia, in Continent-Ocean Interactions in the East Asian Marginal Seas, Geophys. Monogr. Ser., vol. 149, edited by P. Clift et al., pp. 255-282, AGU, Washington, D. C.

Clift, P. D., H. Schouten, and P. Vannucchi (2009), Arc-continent collisions, subduction mass recycling and the maintenance of the continental crust, in Earth Accretionary Systems in Space and Time, Geol. Soc. Spec. Publ., $318,75-103$

Conrad, C. P., and P. Molnar (1997), The growth of Rayleigh-Taylor-type instabilities in the lithosphere for various rheological and density structures, Geophys. J. Int., 129, 95-112, doi:10.1111/j.1365246X.1997.tb00939.x.

Copeland, P., T. M. Harrison, and M. T. Heizler (1990), 40Ar/39Ar singlecrystal dating of detrital muscovite and K-feldspar from Leg 116, southern Bengal Fan: Implications for the uplift and erosion of the Himalayas, Proc. Ocean Drill. Program Sci. Results, 116, 93 -114, doi:10.2973/odp. proc.sr.116.119.1990.

DeCelles, P. G., et al. (1987), Laramide thrust-generated alluvial-fan sedimentation, Sphinx Conglomerate, southwestern Montana, Am. Assoc. Pet. Geol. Bull., 71, 135-155.

Dercourt, J., et al. (1986), Geological evolution of the Tethys belt from the Atlantic to the Pamirs since the Lias, Tectonophysics, 123, 241-315, doi:10.1016/0040-1951(86)90199-X.

Dercourt, J., L. E. Ricou, and B. Vrielynck (1993), Atlas Tethys, Paleoenvironmental Maps, 307 pp., Gauthier-Villars, Paris.

Dewey, J. F., and J. M. Bird (1970), Mountain belts and the new global tectonics, J. Geophys. Res., 75, 2625-2647, doi:10.1029/JB075i014p02625.

Deynoux, M., P. Affaton, R. Trompette, and M. Villeneuve (2006), PanAfrican tectonic evolution and glacial events registered in Neoproterozoic to Cambrian cratonic and foreland basins of West Africa, J. Afr. Earth Sci., 46, 397-426, doi:10.1016/j.jafrearsci.2006.08.005

Drachev, S. S., L. A. Savostinc, V. G. Groshevd, and I. E. Brunie (1998), Structure and geology of the continental shelf of the Laptev Sea, Eastern Russian Arctic, Tectonophysics, 298, 357-393, doi:10.1016/S00401951(98)00159-0.

Emery, K. O., E. Uchupi, C. O. Bowin, J. Phillips, and S. W. Simpson (1975), Continental margin off western Africa: Cape St. Francis (South Africa) to Walvis Ridge (South West Africa), Am. Assoc. Pet. Geol. Bull., $59,3-59$.

England, P., and P. Molnar (1997), Active deformation of Asia: From kinematics to dynamics, Science, 278, 647-650, doi:10.1126/ science. 278.5338 .647

Flesch, L. M., W. E. Holt, A. J. Haines, and B. Shen-Tu (2000), Dynamics of the Pacific-North American plate boundary in the western United States, Science, 287, 834-836, doi:10.1126/science.287.5454.834

Galloway, W. E., D. G. Bebout, W. L. Fisher, J. B. Dunlap Jr., R. CabreraCastro, and T. M. Scoot (1991), Cenozoic, in The Gulf of Mexico Basin, edited by A. Salvador, pp. 245-324, Geol. Soc. of Am., Boulder, Colo. Ghosh, P., C. N. Garzione, and J. M. Eiler (2006), Rapid uplift of the Altiplano revealed through $13 \mathrm{C}-18 \mathrm{O}$ bonds in paleosol carbonates, Science, 311, 511-515, doi:10.1126/science.1119365.

Gnibidenko, H. S., and I. I. Khvedchuk (1982), The tectonics of the Okhotsk Sea, Mar: Geol., 50, 155-198, doi:10.1016/0025-3227(82)90138-4.

Griffin, W. L., and S. Y. O'Reilly (1987), Is the continental Moho the crust mantle boundary?, Geology, 15, 241-244, doi:10.1130/00917613(1987)15<241:ITCMTC $>2.0$. CO; 2 .

Haq, B. U., J. Hardenbol, and P. R. Vail (1987), Chronology of fluctuating sea levels since the Triassic, Science, 235, 1156-1167, doi:10.1126/ science.235.4793.1156

Harrison, C. G. A. (1994), Rates of continental erosion and mountain building, Int. J. Earth Sci., 83, 431-447.

Harrison, C. G. A. (1998), The hypsography of the ocean floor, Phys. Chem. Earth, 23, 761-774, doi:10.1016/S0079-1946(98)00090-1.

Harrison, C. G. A. (1999), Constraints of ocean volume change since the Archean, Geophys. Res. Lett., 26, 1913-1916, doi:10.1029/ 1999GL900425.

Hartley, A. J., T. Sempere, and G. Woerner (2007), Rapid late Miocene rise of the Bolivian Altiplano: Evidence for removal of mantle lithosphere, discussion, Earth Planet. Sci. Lett., 259, 625-629, doi:10.1016/ j.epsl.2007.04.012.

Horton, B. K., and P. G. DeCelles (1997), The modern foreland basin system adjacent to the central Andes, Geology, 25, 895-898, doi:10.1130/0091-7613(1997)025<0895:TMFBSA $>2.3 . C O ; 2$.

Houseman, G. A., and P. Molnar (1997), Gravitational (Rayleigh-Taylor) instability of a layer with non-linear viscosity and convective thinning of continental lithosphere, Geophys. J. Int., 128, 125-150, doi:10.1111/ j.1365-246X.1997.tb04075.x.

Huerta, A., L. Royden, and K. Hodges (1996), The interdependence of deformational and thermal processes in mountain belts, Science, 273, 637-639, doi:10.1126/science.273.5275.637.

Huerta, A., L. Royden, and K. Hodges (1998), The thermal structure of collisional orogens as a response to accretion, erosion, and radiogenic heating, J. Geophys. Res., 103, 15,287-15,302, doi:10.1029/98JB00593.

Huerta, A., L. Royden, and K. Hodges (1999), The effects of accretion and erosion on the metamorphic evolution of collisional orogens, J. Metamorph. Geol., 17, 349-366, doi:10.1046/j.1525-1314.1999.00204.x.

Hynes, A. (2001), Freeboard revisited: Continental growth, crustal thickness change and Earth's thermal efficiency, Earth Planet. Sci. Lett., 185 , 161-172, doi:10.1016/S0012-821X(00)00368-X

Johnson, M. R. W. (1994), Volume balance of erosional loss and sediment deposition related to Himalaya uplifts, J. Geol. Soc., 151, 217-220, doi:10.1144/gsjgs.151.2.0217.

Kaufman, P. S., and L. H. Royden (1994), Lower crustal flow in an extensional setting: Constraints from the Halloran Hills region, eastern Mojave Desert, California, J. Geophys. Res., 99, 15,723-15,739, doi:10.1029/ 94JB00727.

Kay, R. W., and S. M. Kay (1993), Delamination and delamination magmatism, Tectonophysics, 219,177-189, doi:10.1016/0040-1951(93)90295-U.

Keen, C. E., W. A. Kay, and B. C. MacLean (1991), A deep seismic reflection profile across the Nova Scotia continental margin, offshore eastern Canada, Can. J. Earth Sci., 28, 1112-1120, doi:10.1139/e91-100.

Kominz, M. A. (1984), Oceanic ridge volumes and sea level change-An error analysis, in Interregional Unconformities and Hydrocarbon Accumulation, edited by J. Schlee, pp. 109-127, Am. Assoc. of Petrol. Geol., Tulsa, Okla.

Kuhlemann, J., W. Frisch, I. Dunkl, and B. Szekely (2001), Quantifying tectonic versus erosive denudation by the sediment budget: The Miocene core complexes of the Alps, Tectonophysics, 330, 1-23, doi:10.1016/ S0040-1951(00)00209-2. 
Lavier, L. L., M. S. Steckler, and F. Brigaud (2001), Climatic and tectonic controls on the Cenozoic evolution of the West African margin, Mar Geol., 178, 63-80, doi:10.1016/S0025-3227(01)00175-X.

Lithgow-Bertelloni, C., and P. G. Silver (1998), Dynamic topography, plate driving forces and the African superswell, Nature, 395, 269-272, doi: $10.1038 / 26212$.

Lowman, J. P., and G. T. Jarvis (1995), Mantle convection models of continental collision and breakup incorporating finite thickness plates, Phys Earth Planet. Inter., 88, 53-68, doi:10.1016/0031-9201(94)05076-A.

Mangino, S., and K. Priestley (1998), The crustal structure of the southern Caspian region, Geophys. J. Int., 133, 630-648, doi:10.1046/j.1365246X.1998.00520.x

McElroy, B., and B. Wilkinson (2005), Climatic control of continental physiography, J. Geol., 113, 47-58, doi:10.1086/425968.

McMillan, M. E., P. L. Heller, and S. L. Wing (2006), History and causes of post-Laramide relief in the Rocky Mountain orogenic plateau, Geol. Soc. Am. Bull., 118, 393-405, doi:10.1130/B25712.1.

Meredith, D. J., and S. S. Egan (2002), The geological and geodynamic evolution of the eastern Black Sea basin: Insights from 2-D and 3-D tectonic modelling, Tectonophysics, 350, 157-179, doi:10.1016/S00401951(02)00121-X

Métivier, F., Y. Gaudemer, P. Tapponnier, and M. Klein (1999), Mass accumulation rates in Asia during the Cenozoic, Geophys. J. Int., 137 280-318, doi:10.1046/j.1365-246X.1999.00802.x.

Miller, K. G., M. A. Kominz, J. V. Browning, J. D. Wright, G. S. Mountain, M. E. Katz, P. J. Sugarman, B. S. Cramer, N. Christie-Blick, and S. F. Pekar (2005), The Phanerozoic record of global sea-level change, Science, 310, 1293-1298, doi:10.1126/science.1116412.

Milliman, J. D., and J. P. M. Syvitski (1992), Geomorphic/tectonic control of sediment discharge to the ocean: The importance of small mountainous rivers, J. Geol., 100, 525-544.

Molnar, P. (1988), A review of geophysical constraints on the deep structure of the Tibetan Plateau, the Himalaya and the Karakoram, and their tectonic implications, Philos. Trans. R. Soc. Ser. A, 326, 33-88, doi:10.1098/rsta.1988.0080.

Müller, R. D., M. Sdrolias, C. Gaina, B. Steinberger, and C. Heine (2008), Long-term sea-level fluctuations driven by ocean basin dynamics, Science, 319, 1357-1362, doi:10.1126/science.1151540.

Nikishin, A. M., M. V. Korotaev, A. V. Ershov, and M. F. Brunet (2003), The Black Sea basin: Tectonic history and Neogene-Quaternary rapid subsidence modelling, Sediment. Geol., 156, 149-168, doi:10.1016/ S0037-0738(02)00286-5.

Nisbet, E. G. (1987), The Young Earth: An Introduction to Archaean Geology, 402 pp., Allen \& Unwin, London.

Patzkowsky, M. E., L. H. Smith, P. J. Markwick, C. J. Engberts, and E. D. Gyllenhaal (1991), Application of the Fujita-Ziegler paleoclimate model: Early Permian and Late Cretaceous examples, Palaeogeogr. Palaeoclimatol. Palaeoecol., 86, 67-85, doi:10.1016/0031-0182(91)90006-D.

Piper, D. J. W., and W. R. Normark (2001), Sandy Fans-From Amazon to Hueneme and beyond, Am. Assoc. Pet. Geol. Bull., 85, 1407-1438.

Pitman, W. C., III (1978), Relationship between eustasy and stratigraphic sequences of passive margins, Geol. Soc. Am. Bull., 89, 1389-1403, doi:10.1130/0016-7606(1978)89<1389:RBEASS $>2.0 . C O ; 2$

Plank, T., and C. H. Langmuir (1993), Tracing trace elements from sediment input into volcanic output at subduction zones, Nature, 362, 739742, doi:10.1038/362739a0

Reymer, A., and G. Schubert (1984), Phanerozoic addition rates to the continental crust and continental growth, Tectonics, 3, 63-77, doi:10.1029/TC003i001p00063.

Rodger, M., A. B. Watts, C. J. Greenroyd, C. Peirce, and R. W. Hobbs (2006), Evidence for unusually thin oceanic crust and strong mantle beneath the Amazon Fan, Geology, 34, 1081-1084, doi:10.1130/ G22966A.1.

Rowley, D. B. (1996), Age of initiation of collision between India and Asia: A review of stratigraphic data, Earth Planet. Sci. Lett., 145, 1-13, doi:10.1016/S0012-821X(96)00201-4

Royden, L. (1993a), The evolution of retreating subduction boundaries formed during continental collision, Tectonics, 12, 629-638, doi:10.1029/92TC02641.

Royden, L. (1993b), The tectonic expression of slab pull at continental convergent boundaries, Tectonics, 12, 303-325, doi:10.1029/92TC02248.

Rudnick, R. L. (1995), Making continental crust, Nature, 378, 573-578.

Saintot, A., M.-F. Brunet, F. Yakovlev, M. Sebrier, R. A. Stephenson, A. Ershov, F. Chalot-Prat, and T. McCann (2006), The Mesozoic-Cenozoic tectonic evolution of the Greater Caucasus, in European Lithosphere Dynamics, edited by D. G. Gee and R. A. Stephenson, pp. 277-289, Geol. Soc., London.

Schubert, G., and A. P. S. Reymer (1985), Continental volume and freeboard through geological time, Nature, 316, 336-339, doi:10.1038/ $316336 \mathrm{a} 0$
Sclater, J. G., and P. A. F. Christie (1980), Continental stretching: An explanation of the post mid-Cretaceous subsidence of the central North Sea basin, J. Geophys. Res., 85, 3711-3739, doi:10.1029/ JB085iB07p03711.

Scotese, C. R. (1991), Jurassic and Cretaceous plate tectonic reconstructions, Palaeogeogr. Palaeoclimatol. Palaeoecol., 87, 493-501, doi:10.1016/0031-0182(91)90145-H

Sengor, A. M. C. (1984), The Cimmeride Orogenic System and the Tectonics of Eurasia, 241 pp., Geol. Soc. of Am., Boulder, Colo.

Stewart, R. J., B. Hallet, P. K. Zeitler, M. A. Malloy, C. M. Allen, and D. Trippett (2008), Brahmaputra sediment flux dominated by highly localized rapid erosion from the easternmost Himalaya, Geology, 36 , 711-714, doi:10.1130/G24890A.1

Stoakes, F. A., C. V. Campbell, R. Cass, and N. Ucha (1991), Seismic stratigraphic analysis of the Punta del Este Basin, offshore Uruguay, South America, Am. Assoc. Pet. Geol. Bull., 75, 219-240.

Thatcher, W., G. R. Foulger, B. R. Julian, J. Svarc, E. Quilty, and G. W. Bawden (1999), Present-day deformation across the Basin and Range Province, western United States, Science, 283, 1714-1718, doi:10.1126 science.283.5408.1714

Turcotte, D. L., and G. Schubert (2002), Geodynamics, 456 pp., Cambridge Univ. Press, New York.

Tuttle, M. L. W., R. R. Charpentier, and M. E. Brownfield (1999), The Niger Delta Petroleum System: Niger Delta Province, Nigeria, Cameroon, and Equatorial Guinea, Africa, U.S. Geol. Surv., Reston, Va.

Van Balen, R. T., L. Lenkey, F. Horvath, and F. Cloetingh (1999), Twodimensional modelling of stratigraphy and compaction-driven fluid flow in the Pannonian Basin, Geol. Soc. Spec. Publ., 156, 391-414.

Vannucchi, P., P. D. Clift, and J. Phipps-Morgan (2008), Constraining rates of crustal recycling using geophysical and geochemical methods, Geochim. Cosmochim. Acta, 72, suppl. 1, 975

Veizer, J., and S. L. Jansen (1985), Basement and sedimentary recycling2: Time dimension to global tectonics, J. Geol., 93, 625-643.

Vincent, S. J., A. C. Morton, A. Carter, S. Gibbs, and T.-G. Barabadze (2007), Oligocene uplift of the western Greater Caucasus: An effect of initial Arabia-Eurasia collision, Terra Nova, 19, 160-166, doi:10.1111/ j.1365-3121.2007.00731.x.

Wade, J. A., and B. C. MacLean (1990), The geology of the southeastern margin of Canada, part 2-Aspects of the geology of the Scotian Basin from recent seismic and well data, in Geology of the Continental Margin of Eastern Canada, edited by M. J. Keen and G. L. Williams, pp. 167238, Geol. Soc. of Am., Boulder, Colo.

Wang, Q., et al. (2001), Present-day crustal deformation in China constrained by global positioning system measurements, Science, 294, 574-577, doi:10.1126/science.1063647.

Whitehead, J. A. (2003), Laboratory Studies of Mantle Convection With Continents and Other GFD Problems, Recent Research Developments in Fluid Dynamics, 199 pp., Transworld Res. Network, Kerala, India.

Wise, D. U. (1974), Continental margins, freeboard and the volumes of continents and oceans through time, in The Geology of Continental Margins, edited by A. E. M. Nairn and F. G. Stehli, pp. 45-58, Springer, New York.

Woodhead, J. D., and D. G. Fraser (1985), Pb, Sr, and 10Be isotopic studies of volcanic rocks from the northern Mariana Islands: Implications for magma genesis and crustal recycling in the western Pacific, Geochim. Cosmochim. Acta, 49, 1925-1930, doi:10.1016/0016-7037(85)90087-0.

Wu, Y., K. E. Louden, T. Funck, H. R. Jackson, and S. A. Dehler (2006), Crustal structure of the central Nova Scotia margin off eastern Canada, Geophys. J. Int., 166, 878-906, doi:10.1111/j.1365-246X.2006.02991.x.

Yin, A., and T. M. Harrison (2000), Geologic evolution of the HimalayanTibetan orogens, Annu. Rev. Earth Planet. Sci., 28, 211-280, doi:10.1146/annurev.earth.28.1.211

Yoshida, M. (2007), Geochronological data evaluation; implications for the Proterozoic tectonics of east Gondwana, Gondwana Res., 12, 228-241, doi:10.1016/j.gr.2006.10.013

Yuan, X., S. V. Sobolev, and R. Kind (2002), Moho topography in the central Andes and its geodynamic implications, Earth Planet. Sci. Lett., 199, 389-402.

Zhang, Y. (2005), Global tectonic and climatic control of mean elevation of continents, and Phanerozoic sea level change, Earth Planet. Sci. Lett., 237, 524-531, doi:10.1016/j.epsl.2005.07.015.

P. D. Clift, Department of Geology and Petroleum Geology, School of Geosciences, University of Aberdeen, Meston Building, Kings College, Aberdeen AB24 3UE, UK. (p.clift@abdn.ac.uk)

J. A. Whitehead, Department of Physical Oceanography, Woods Hole Oceanographic Institution, MS 21, Woods Hole, MA 02543, USA. (jwhitehead@whoi.edu) 